\title{
Working
}

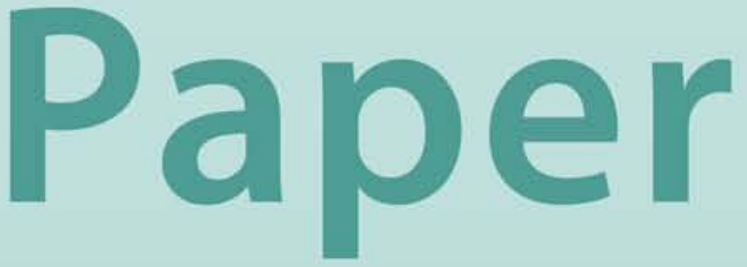


The Macroeconomics of Remittances:

The Case of Tajikistan

Alexei Kireyev 


\title{
IMF Working Paper
}

Policy Development and Review Department

\section{The Macroeconomics of Remittances: The Case of Tajikistan}

\author{
Prepared by Alexei Kireyev ${ }^{1}$ \\ Authorized for distribution by Patricia Alonso-Gamo
}

January 2006

\begin{abstract}
This Working Paper should not be reported as representing the views of the IMF. The views expressed in this Working Paper are those of the author(s) and do not necessarily represent those of the IMF or IMF policy. Working Papers describe research in progress by the author(s) and are published to elicit comments and to further debate.

The paper seeks to assess the macroeconomic implications of large-scale inward remittances for a small open economy. By including remittances in several standard models, the paper concludes that the overall macroeconomic impact of remittances is likely to be ambiguous. The impact depends on the structural characteristics of the receiving country, in particular its consumption and investment patterns, and its capacity to manage large financial inflows. As data deficiencies and methodological problems associated with remittances preclude crosscountry empirical investigation, the paper illustrates these findings with data on Tajikistan, where remittances as a share of GDP are among the highest in the world. The paper also evaluates the pros and cons of remittances in a broader political economy context.
\end{abstract}

JEL Classification Numbers: F41; F22; O15

Keywords: Remittances, labor mobility, international migration, Tajikistan

Author(s) E-Mail Address: akireyev@imf.org

\footnotetext{
${ }^{1}$ The author is grateful to Zuzana Brixiova, Judith Campbell, Robert Christiansen, Craig Dudley, Ben Kelmanson, Carlos Piñerúa, Marta Ruiz Arranz, Jens Reinke, Peter Winglee, and Azam Zununov for their helpful comments.
} 
I. Introduction

II. Labor Migration and Remittances in Tajikistan.

A. Methodological Constraints .

B. The Magnitude of Remittances to Tajikistan .................................................. $\underline{5}$

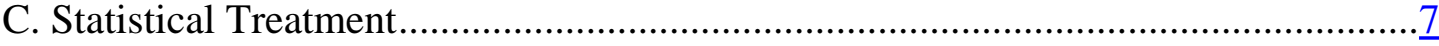

III. The Macroeconomic Impact of Remittances ....................................................

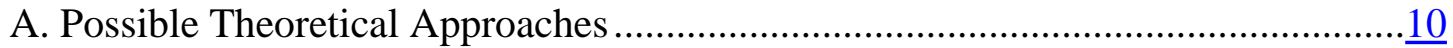

B. The Contribution of Remittances to Development …...................................... $\frac{13}{15}$

C. Policy Challenges of Remittances..............................................................

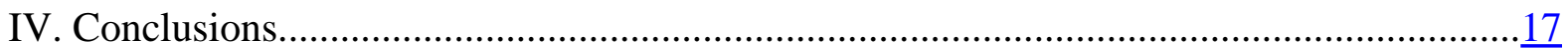

V. Appendix I. Possible Theoretical Treatment of Remittances ........................................19

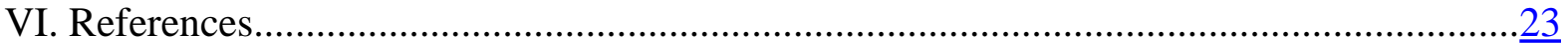

Box

1. Estimates of Emigration and Remittances to Tajikistan ............................................ $\mathbb{7}$

Figures

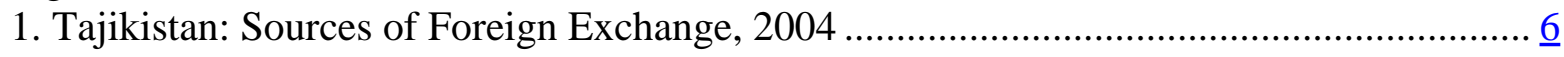

2. Remittances Through the Banking System ................................................................ $\underline{6}$

3. The Keynesian Model ...................................................................................... 19

4. The Mundell-Fleming Model.................................................................................. 19

5. The Rybczynski Effect............................................................................................. 20

Tables

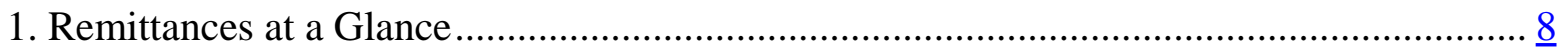

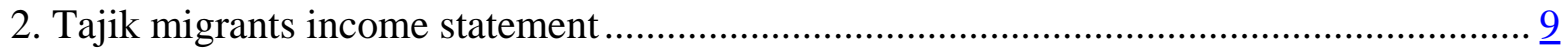




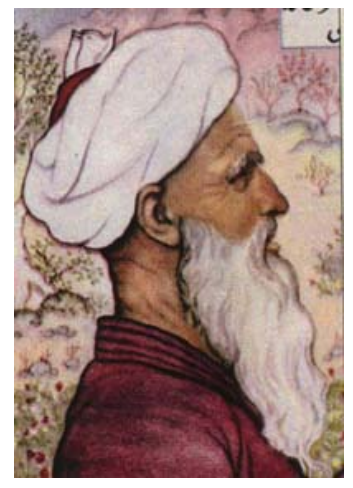

Пулу мулку коргурези хама майли чисм аст

Лекин илму донишу акл чони маро кисм аст.

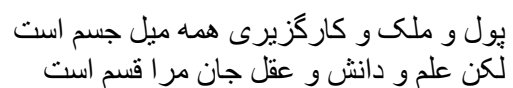

Temptations of the flesh are money, land, and a day of celebration; Science, knowledge, and reason are for my soul temptation.

Rudaki, Tajik-Persian poet $(860$ - c. 941$)$.

\section{INTRODUCTION}

Labor migration and associated remittances have proven to be a largely unexpected result of the transition of some formerly planned economies to market. Tajikistan is one such example. The country is emerging from years of economic instability and civil distress and gradually reestablishing itself. The breakdown of economic links after the demise of the Soviet Union, civil unrest, poor governance and macroeconomic management, strained political relations with neighbors, and the region's overall geopolitical instability-all contributed to chaotic external economic relations during the 1990s. The export base narrowed to a few products (aluminum, cotton, electricity, fruits, and vegetables), traditional markets were lost, and the payments system collapsed. External borrowing expanded uncontrollably, and enterprises were forced to engage in barter exchange, often without proper authorization. This often resulted in a failure to meet commitments, leaving many enterprises with government-guaranteed arrears. Daily household consumption relied on humanitarian aid and imports of staples by shuttle traders. Eventually, Tajik families found themselves with no option but to send at least one member of the household abroad to seek income. This was the only means of guaranteeing the survival of those left behind.

Migration from Tajikistan and the consequent remittances have been unprecedented in their magnitude and economic impact. No other country has seen its workforce decline by around 20 percent in a decade, nor flows of remittance reach around 50 percent of GDP. And no other country has addressed so well the hurdles of transition from a planned to a market economy. Tajikistan has achieved this without substantial and protracted recourse to aid (of which it by now receives only negligible amounts), and by purely market-based means, simply by exporting its main commodity of comparative advantage — cheap labor. As the public sector was struggling with the loss of transfers from Moscow and the resulting fiscal imbalances, a lack of experience in monetary and exchange rate management, institutional deficiencies and governance problems, the private sector-as could have been expectedtook its destiny into its own hands. With nothing else to offer to the market, people decided to sell their labor and support their households. This decision was taken spontaneously and with determination, by thousands of those not only with education and work experience (e.g., 
teachers, doctors, engineers), but also unskilled laborers (odd-job men) and high-school graduates. The outflow of labor was particularly high in the 1990s, but the knowledge that the country was surviving largely on their remittances only emerged much later, in 20032004, when the balance of payments first began to capture massive private transfers through the banking system.

The purpose of this paper is to contribute to the discussion of the macroeconomics of remittances. Using the example of Tajikistan, where actual remittances as a share of GDP are among the highest in the world, the paper seeks to assess the macroeconomic impact of remittances by fitting them into a number of standard macroeconomic models. The paper consists mainly of a theoretical treatment of remittances with some factual illustrations, and is organized as follows: Section II presents known facts about labor migration from, and remittances to, Tajikistan; Section III reviews a number of theoretical models and evaluates the pros and cons of remittances in this broader context; and Section IV provides conclusions.

\section{LABOR MigRATION AND REMITTANCES IN TAJIKISTAN}

\section{A. Methodological Constraints}

The overall understanding of migration and remittances is inadequate given the importance of this economic phenomenon. An ad hoc survey of the European Union (EU) member states undertaken by Eurostat in 2004 shows that, while most European countries compile data on the overall amounts and estimate the share of remittances sent to developing countries, they all harbored serious reservations about their quality (European Commission, 2004). Data on remittance flows from the EU to developing countries are not systematically reported, and a geographical breakdown of remittance flows to third countries, including developing countries, is available only for some EU countries. In most countries there is a minimum threshold for remittances below which individual transfers are simply not recorded. ${ }^{2}$ While some countries estimate the transfers below this threshold in the balance of payments, many others simply ignore them, resulting in an underestimation of remittances. The analysis of the evolution of remittances over time also presents a problem, as improvements in reporting systems, lower transaction costs, and a potential shift from informal to formal channels of remittance flows, all complicate intertemporal comparability of data.

Migration and remittances as statistical concepts are defined only vaguely. An International Technical Meeting on Measuring Migrants Remittances in early 2005 identified a number of areas where the statistical treatment of remittances needed to be improved (for details, see Alfieri et al., 2005; Hussain, 2005). In particular, balance of payments conventions do not provide a robust basis for measuring remittances: the one-year rule does not allow

\footnotetext{
${ }^{2}$ For example, the United States does not require reporting remittances under US $\$ 10,000$ and the EU threshold is $€ 12,500$.
} 
identification of all migrants; the distinction between remittances and other private transfers is somewhat blurred; there is no methodology for compiling information about informal flows; and the impact of remittances on development is measured by household surveys in the sending and receiving countries. ${ }^{3}$ The statistical treatment of remittances is further complicated by differences in the definition of a migrant (Bilsborrow, et al., 1997). Broadly, three balance of payments components are seen as most relevant for capturing remittances (Reinke and Patterson, 2005): (i) compensation of employees-earnings by resident individuals for work performed in another economy and paid for by residents of this other economy; (ii) workers' remittances_current transfers by migrants who are employed in new economies and considered residents there and nonresidents of the home economy; (iii) migrants' transfers - the flow of goods and changes in financial items that occur with migration (to or from the migrant as resident to the same person as nonresident).

For the purposes of this paper a broad concept of migrant is used that includes all people who left Tajikistan and are the source of remittances to Tajikistan. This treatment is broader than the ILO definition of migrant workers as "people who are permitted to be engaged in economic activity in the country other than the country of their origin" (Bilsborrow, 1997). Therefore, the maximum estimates of migrants in this paper include four groups of people: seasonal migrants (Tajiks who work abroad but return home annually); settled migrants (Tajiks on long-term contacts abroad); permanent emigrants (mainly ethnic Russians and people of other nationalities who left Tajikistan permanently but remit part of their income to relatives left in the country); and shuttle migrants (traders whose commercial activity is related to regular departures and returns to Tajikistan).

\section{B. The Magnitude of Remittances to Tajikistan}

The sheer magnitude of remittances to Tajikistan is staggering. Depending on the underlying assumptions, the estimation of remittance inflows may plausibly fall within a range of US\$400 million to US\$1 billion a year, or from 20 percent to almost 50 percent of GDP. ${ }^{4}$ Considering only remittances through the banking system, net foreign exchange inflows from remittances are comparable in magnitude with the net inflows from trade, five times the externally-financed public investment program, and ten times higher than foreign direct investment and any other private inflows.

\footnotetext{
${ }^{3}$ New proposals, which will focus on household-to-household transfers and will help to rectify many of these problems, are being discussed in the IMF Committee on Balance of Payments Statistics.

${ }^{4}$ This is very high by international standards, compared with, for example, Moldova, where recorded remittances reach 25 percent of GDP, Lesotho (19 percent), Jordan (18 percent), and Albania (15 percent). Most other traditionally high-remittance countries (Bangladesh, Bosnia, Egypt, Morocco, Pakistan, Tonga, Tunisia, and Vietnam) have remittances of less than 10 percent of GDP. See IMF (2005) and World Bank (2005) for further comparisons and recent trends.
} 
Figure 1. Tajikistan: Sources of Foreign Exchange, 2004

(In percent of GDP)

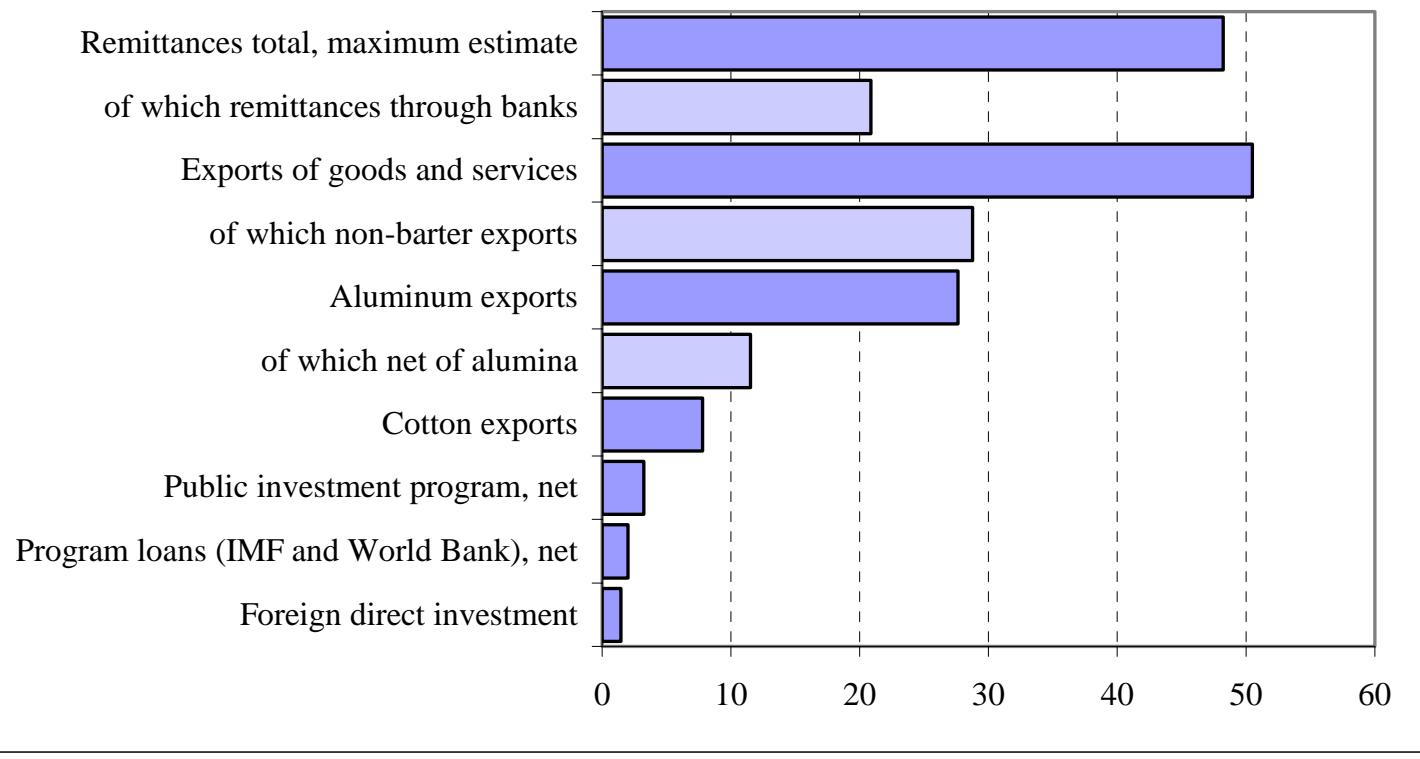

The role of labor migration and remittances in Tajikistan's development in recent years has been substantial. Annual labor migration increased steadily in the 1990s and peaked in 1999. Over 90 percent of migrants who left Tajikistan after the civil war, did so to seek job opportunities, higher income, and improved living standards. With a trend towards economic stabilization in recent years, labor migration has moderated, although its annual levels remain high. The balance of payments records of remittances made through the banking system increased almost tenfold in 2001-2004. This was a result of improved confidence in the banking system and the elimination at end-2001 of a 30 percent tax on international transfers allowing transfers of foreign exchange through Tajik banks without opening a current account.

The official data on remittances have been revised recently. At end-2004, the official balance of payments statistics, which only captures transfers through the banking system, reported remittances of US\$433 million (21 percent of GDP). A survey conducted in early 2005 showed that this number may include some receipts for exports of fruits and vegetables by small private traders, who use interpersonal bank transfers to repatriate the proceeds of such exports to Tajikistan. In mid-2005 the authorities revised the balance of payments data on remittance inflows, reducing them by 40 percent to 12 percent of

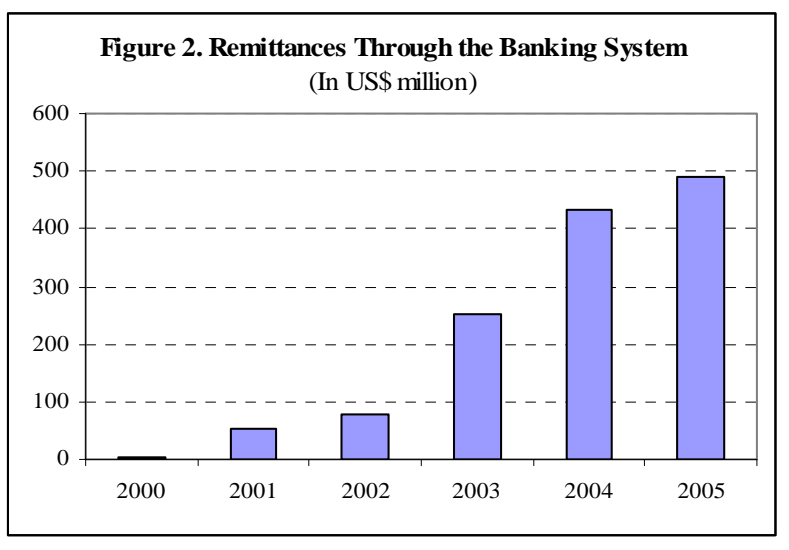
GDP, and reclassified a substantial portion as exports. 
The estimates of migration and remittances are erratic and vary within wide margins (Box 1).

\section{Box 1. Estimates of Emigration and Remittances to Tajikistan}

International Organization for Migration: More than 632,000 Tajiks, 18 percent of the adult population, are compelled to leave their country in order to support their families. (IOM News, June 2004, p.19). About 1 million people, or 15 percent of the population, live in households whose main source of income is derived from a family member working abroad. (Olimova, Saodat, and Igor Bosc, 2003, p. 20). An estimated 620,000 Tajik seasonal workers travel abroad each year, primarily to Russia but also to neighboring Kazakhstan, Kyrgyzstan, and Uzbekistan, according to a recent IOM report (IRIN News, Reuters, May 18, 2005).

World Bank: According to the World Bank's Poverty Assessment Update (June 2004), migration has played a major role in the high rate of poverty reduction experienced since 1999. About 17 percent of workers reside permanently or temporarily outside Tajikistan. Further, the Tajikistan Living Standard Survey conducted in 2003 indicates that remittances and other transfers made up about 10 percent of average household income in 2003, ranking it second as a source of cash income after wages. A Trade Diagnostic Study estimated remittances at US\$471 million, compared to an official estimate of US\$187 million in 2003. It was also found that cash carried by individuals was a popular means of remittance transfer, accounting for 54 percent of total remittances.

All-Russia population census (2002): The number of registered Tajik citizens living in Russia was 64,000, and the number of temporary Tajik visitors was 26,000. The largest diaspora of Tajiks is located in and around Moscow. Other large diasporas are concentrated around St. Petersburg and the industrial centers in the Urals (On-line report, http://www.gks.ru).

Institute of Economic Forecasting at the Russian Academy of Sciences: About 700,000 ethnic Tajiks and over 400,000 ethnic Russians, who left Tajikistan mainly in 1989-1995, are now working in Russia. The remaining emigration potential of ethnic Russians from Tajikistan is around 100,000 (On-line report, August 2003).

Russian Federal Migration Service: The number of illegal Tajik migrants in Russia is in the region of 600,000-800,000, or 10-15 percent of all illegal immigrants. (Igor Yunash, Deputy Director, Federal Migration Service, Ministry of Internal Affairs).

Ministry of Labor and Social Protection of Tajikistan: As of August 2003, about 420,000 Tajiks were working abroad as labor migrants (Tajikistan Development Gateway).

\section{Statistical Treatment}

As indicated above, the inflows recorded in Tajikistan as remittances through the banking system represent a mixture of remittances and export proceeds. According to estimates by the National Bank of Tajikistan (NBT), such trade-related payments may represent up to 40 percent of total remittances, which would imply an overestimation of workers' remittances in this line of the balance of payments. Based on a survey of banks and their clients, the NBT established the following statistical treatment of bank transfers endorsed by a Fund technical assistance mission: all single transfers of less than US $\$ 1,000$ plus 50 percent of transfers between US $\$ 1,000$ and US $\$ 3,000$ would be considered workers' remittances; all transfers of 
more than US $\$ 3,000$ and 50 percent of transfers between US $\$ 1,000$ and US $\$ 3,000$ would be reclassified as exports.

All remittances through the banking system are shown as current transfers in the balance of payments, although some can be treated either as trade-related payments or income.

According to the IOM (2003) study of migration from Tajikistan, there are three main types of labor migrants:

- Migrants on official or informal contracts with the recipient enterprises ( 20 percent of all migrants). As such industrial and trade enterprises operate year round, the Tajik migrants usually stay abroad for longer than a year and transfer a substantial part of their salaries to relatives in Tajikistan. Their transfers of salaries through the banking system are shown as remittances.

- Crews for moonlighting construction and agricultural workers (50 percent). These migrants usually work abroad from MarchNovember, during the most active construction and agricultural season in Russia, and return to Tajikistan in the winter, remitting their incomes sporadically or simply bringing them in cash. Although their transfers should be captured as income in the balance of payments, they are still shown as remittances, as no reliable information on the length of actual stay is available. Confusion of income and transfers is a widespread phenomenon in many countries, as the differentiation by the 12-month rule is difficult to assess in practice.

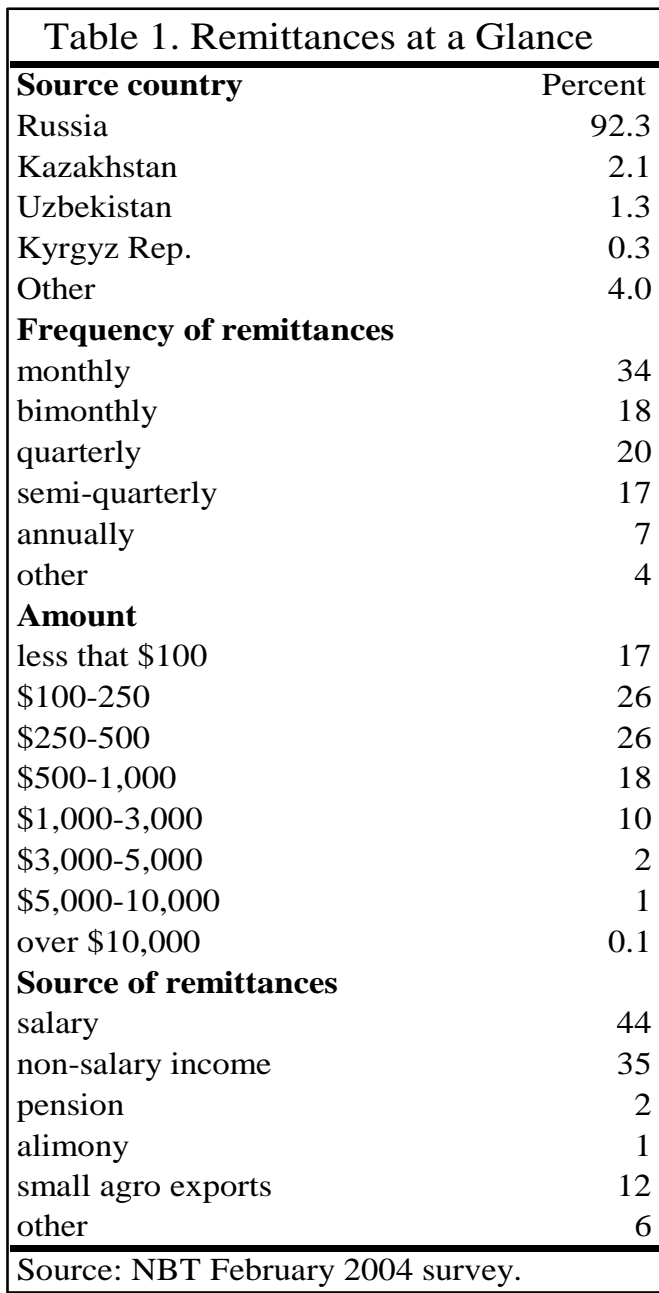

- Shuttle traders (30 percent). The majority of these are the best educated of Tajik migrants and stay for a short period of time and function either individually or through established networks that operate continuously. Their remittances through the banking system represent a mix of family support, which should be shown as income, with export receipts, which should be included in exports. The classification of bank transfers by shuttle traders depends on the way such transfers are sent and on the type of the recipient.

In addition, the magnitude of remittances flowing through the channels outside the banking system are largely unknown. International experience suggests five main channels for remitting funds across borders: interbank transfers, formal non-bank money transfer operators, post offices, cash and commodities carriers, and informal money transfer operators. All are used to some extent in Tajikistan, but three other channels are particularly important: 
- Transportation of cash. Because of the threat of extortion and physical abuse at any checkpoint on the way to Tajikistan, cash deliveries are made mainly by air. With an average of 23 flights a week to Dushanbe from Russia by Tajik Air and some local airlines, each of which uses TU154s seating 160-180 people, air transport is capable of bringing in 200,000 people a year to Tajikistan. If half this number carries on average US $\$ 1,000$, at least US\$100 million (5 percent of GDP) should be added to remittances.

- Money "throwing." For relatively large amounts—usually in excess of US\$ \$3,000—an illegal money transfer network known as "перекидка" (perekidka, from the Russian for throwing or juggling, a card shark's trick) is used, mainly by shuttle traders and moonlighters. As these groups of migrants cannot prove documentarily the legal nature of their income to the remitting bank in Russia, they have to use the throwing system.

- The "hawala" system. There are indications that this traditional money transfer system is used in Tajikistan, primarily for transfers in Asia, in particular with Afghanistan.

For the reasons above, the amount of remittances shown in the balance of payments may not reflect their actual magnitude. Simple calculations suggest the following. Out of the total population of 7 million, about 1.2 million may work either permanently or temporarily outside Tajikistan. This number includes 0.8 million Tajiks (those who live permanently abroad, seasonal workers, and shuttle traders who go abroad regularly) and at least 0.4 million ethnic Russians who left Tajikistan permanently, but remit part of their income to relatives left in Tajikistan. With an average family size in Tajikistan of six persons, the estimate of 1.2 million migrants is consistent with reports that at least one member of each household has left to work abroad or goes there regularly. An average migrant (Tajiks working abroad permanently, seasonal Tajik workers, and ethnic Russians who emigrated permanently) remits at least US $\$ 500$ annually, or less than one half of what is assessed

\begin{tabular}{|lr|}
\hline \multicolumn{2}{|c|}{ Table 2. Tajik migrant's income statement } \\
\hline & US\$ \\
\hline Gross earnings & 2,700 \\
Fixed expenses & 410 \\
Transportation & 330 \\
Border crossing & 30 \\
Other & 50 \\
Variable expenses & 945 \\
Food & 540 \\
Accommodation & 225 \\
Police & 135 \\
Other & 45 \\
Remittances & 1,345 \\
\hline Source: World Bank survey of a typical \\
seasonal worker staying in Russia nine months \\
at a time.
\end{tabular}
by the World Bank as a migrant's income remitted from abroad to Tajikistan. This may suggest a rough maximum estimate of remittances of US\$600 million a year. Remittances outside the banking system, cash carried into the country, and in-kind remittances not captured at all by the official statistics can be comparable in magnitude to receipts from small exports and should be added to this estimate.

\section{Russia is the primary destination for labor migration and the largest source of} remittances. According to the 2003 IOM study, about 84 percent of the Tajik labor migrants remain legally or illegally in Russia; 5 percent in Uzbekistan; 3 percent in Kyrgyzstan; Kazakhstan, Ukraine, and Armenia each account for 1 percent or less. One-half of migrant workers from Tajikistan are employed in housing and industrial construction, one-third in 
trade and services, with the remainder working in gas and oil development, manufacturing, catering, and agriculture. About 60 percent of Tajik migrants have no professional qualifications or skills; those with qualifications primarily include teachers, doctors, engineers and technicians (12 percent); traders ( 7 percent); and farm workers ( 7 percent).

Tajikistan has taken steps toward regularizing labor migration issues with its neighbors. In October 2004, Tajikistan signed an agreement on labor migration with Russia and is seeking to regularize migration rules by simplifying document requirements with other Eurasian Economic Community (EAEC) members.

\section{THE MACROECONOMIC IMPACT OF REMITTANCES}

\section{A. Possible Theoretical Approaches}

Microeconomic theory treats remittances mainly as a household issue. Most literature that has focused on the microeconomics of remittances aims at explaining their patterns, motivation, and the impact on family consumption by using population censuses and other household-level data (see Rapoport and Docquier, 2005 for a detailed review). Most of the studies found that remittances had helped families to survive rough times, to undertake property investment, to access better education and healthcare, or to finance small business activities. As household consumption and investment aggregate to the national level, remittances, from a micro perspective, should have a positive impact on growth.

The literature on the macro impact of remittances remains largely fragmented. It is generally recognized that the long-run impact of remittances on receiving economies depends on whether they are spent on consumption or investment. Since remittances have a substantial impact on income distribution in the receiving countries, some endogenous growth literature associates the macro impact of remittances with their distributive effects. Such studies focus on human capital formation and inequality as key determinants of productivity that have an impact on growth (see Chaimi et al., 2003 and Rapoport and Docquier, 2005 for a discussion). However, there is no identifiable theoretical or empirical study that looks at the impact of remittances on key macroeconomic sectors. Part of the problem is that few of the existing macro models seem immediately suitable for a simultaneous treatment of the impact of labor migration and remittances on growth, fiscal and monetary policy, balance of payments, and the exchange rate. Another problem is that remittances are only a single element in a complex interaction between home countries and the rest of the world, reflecting the exodus of a factor of production on one hand, and international financial inflows on the other, each of which may have opposite macroeconomic implications. What follows are some initial ideas on what could be a starting point for a more in-depth analysis of the macroeconomics of remittances.

Possible theoretical frameworks for assessing the macroeconomics of remittances are summarized in Appendix I, and include the Keynesian model, the Mundell-Fleming model, the Rybczynski effect, and a national accounts approach. 
In using a Keynesian model approach for Tajikistan, the lack of expenditure data on GDP precludes any numerical assessment of the marginal propensity to save, although low bank consumer deposits and quick withdrawals of remittances suggest that it should be very small. At the same time, booming imports, particularly in recent years, in parallel with growing inflows of remittances, suggest that a substantial part of remittances is spent on (imported) consumption. While recovering output after years of civil stress distorts estimations, Tajikistan's marginal propensity to import based on recent data is 0.65 . The impact on growth depends on the interaction between the magnitude of net remittances and the unknown marginal propensity to save. Under this approach, the impact of remittances on growth is likely to be small. But at the same time, the Keynesian model is more appropriate for a large closed economy, where the exchange rate is not particularly relevant.

The Mundell-Fleming model applies the Keynesian approach to a small open economy. While Tajikistan broadly pursues a flexible exchange rate regime, it remains detached from international capital markets, and the Mundell-Fleming framework is applicable. The National Bank of Tajikistan has had difficulties in controlling reserve money, because to meet the demand for domestic currency it has to purchase increasing amounts of foreign exchange, much of which stems from remittances. The growing money demand still reflects mainly the recovery of real GDP, and the authorities have had difficulty in managing the inflationary component of the rapid nominal growth. The impact of remittances on the exchange rate has been ambiguous; strong appreciation pressures that emerged in early 2004 could have been the result of inappropriate monetary management that tried to constrain cash in circulation, rather than a result of the inflow of remittances. At the same time, during most of 2004-early 2005, the foreign exchange market seems to have been close to equilibrium, with the National Bank of Tajikistan intervening on the margins and some nominal depreciation of the exchange rate. Therefore, in Tajikistan the impact of remittances through the monetary channel has so far translated mainly into additional inflationary pressures rather than into real growth, which remains broadly exogenous. So far, the inflationary impact has not been pronounced and affected mainly land and real estate prices and private sector wages.

The Rybczynski theorem if applied to Tajikistan can be seen as a reverse of the original Rybczynski effect: contraction in one factor will lead to an absolute contraction of the output and exports of the product that uses that factor relatively more intensively and an absolute expansion in the output and exports of the good that uses another factor intensively. As labor is assumed to be an abundant factor, its contraction should have an ultra-antitrade production effect. However, the total impact on trade requires the estimation of both production and consumption effects. As a general rule, if the consumption effect is pro-trade, the country's participation in trade will decline with the decline in the abundant factor. The welfare implication of the decline in the abundant factor should be positive, as per capita income of those left in the home country would increase.

But the Rybczynski effect can also lead to an opposite conclusion. Labor is not homogeneous, and the welfare effect of a loss of labor would depend on the composition of the labor force relative to the composition of the migrants. Mostly very old, very young and economically inactive people tend to remain behind in high-emigration countries. Emigration from some countries consists mainly of professionals, from others, mainly laborers. In some 
countries relations with home communities remain strong; in others, people leave for good. The durability of remittance streams are probably affected, as are the choices between consumption and investment. In Tajikistan domestic wages dropped to close to subsistence, with 84 percent of the population living under the poverty line and widespread unemployment and underemployment. In such a case, departure of excess labor in itself should not reduce growth, but rather increase the incomes of those left behind.

In Tajikistan, there are indeed two main export commodities-one labor intensive (cotton) and the other capital intensive (aluminum). Assuming that about half of Tajikistan's 557,000 agricultural workers involved in cotton production produced US\$162 million of exports, while 15,000 aluminum workers produced US\$573 million of aluminum exports, ${ }^{5}$ it is estimated that cotton is about 70 times more labor intensive than aluminum. Therefore, the exodus of labor should have a negative effect at least on cotton, which constitutes 15 percent of GDP and 18 percent of exports. Growth in aluminum is driven by factors other than the modeled re-equilibration between two factors of production because of emigration, and remains largely unaffected by it. Therefore, the ultimate impact on growth is again ambiguous and depends on the degree to which exogenous growth factors would be able to offset the impending decline in the factor-abundant sector.

Under a national accounts approach to remittances, their macroeconomic impact therefore depends mainly on the behavior of the current account. There are at least three channels of impact: a direct channel as remittances are an integral part of the current account, and two indirect channels, through the exchange rate and relative prices.

- $\quad$ The direct impact of remittances on the current account is ambiguous: on the one hand, this net inflow helps improve the current account; on the other hand, as a substantial portion of remittances is spent on imports, they work in the opposite direction by widening the trade deficit. While the actual effect will be determined by remittances' marginal propensity to import, under this approach the current account can never be worse with more remittances. In the extreme case, where remittances' marginal propensity to import is 1 , the current account would be unchanged, otherwise it would improve.

- $\quad$ The indirect impact on the current account through the exchange rate is likely to be negative. An inflow of foreign exchange normally leads to real appreciation, either through a nominal appreciation as demand for domestic currency increases, or through inflation as additional demand pushes consumer prices up. Real appreciation should - all things being equal-worsen the current account, as domestic exports become less competitive internationally.

- $\quad$ The indirect impact on the current account through relative prices is ambiguous and depends on whether remittances are spent on tradables or nontradables. Spending primarily on tradables-irrespective of whether consumer or investment goods—can

${ }^{5}$ Data for 2004. 
either increase their output or prices, or both. If the spillover from this increase to non-tradables is limited, the improvement in the relative prices of tradables should stimulate the production of exportables and contain import growth, thus improving the current account. If remittances are spent primarily on nontradables, there may be an opposite effect - an increase in their relative price would be akin to nominal appreciation, leading to a growing current account deficit.

Alternative frameworks can also be explored in assessing the macroeconomic impact of remittances. In the classical comparative advantage model, for example, exports of labor can be treated either as a regular export of a commodity, in which the country has comparative advantage, or as export of a factor of production. Accordingly, remittances can be seen as export proceeds or as factor income. Cheap labor is a factor of Tajikistan's comparative advantage and its exports can be seen as a market-driven process of realizing this comparative advantage by the private sector. Exports of labor and the consequent remittances will have broadly the same macroeconomic implications as other strongly competitive exports, i.e. the inflow of export revenue, increased domestic consumption, upward pressure on the exchange rate, some inflationary pressures through wages and retail prices. However, if labor is treated merely as a commodity of a comparative advantage, the country may end up in a long-term path of continuous migration, marginal foreign investment and latent growth.

A serious limitation of all these models is that they are static. They can be used only for an assessment of the possible impact at one point in time, whereas in the case of remittances it is likely to be particularly important to look at their impact over time. Dynamic models could help identify the impact of changes on flows of migrants and on the inflows of remittances, as well as the impact of convergence or divergence of wages and incomes on the flows of remittances over time.

\section{B. The Contribution of Remittances to Development}

Labor migration and remittances have had a significant positive macroeconomic impact on Tajikistan. Remittances have cushioned the impact of the civil disruption of the 1990s. As remittances tend to be countercyclical, they have helped much of the population to offset the financial shortfalls stemming from the civil war during 1992-1997, and the difficulties of transition, as well as easing the overall pressures on the government. In the absence of a developed social insurance system and efficient domestic labor market, labor migration and remittances have been for many Tajiks the primary mechanism to address poverty. In this sense, remittances have acted as a social shock absorber.

Remittances have fueled consumption and growth. A rough approximation suggests that the per capita gross national disposable income (GNDI) of Tajikistan (US\$342) at end-2004 is at least 15 percent higher than its GDP per capita (US\$296), and is growing at a faster rate. According to the NBT survey the size of remittances tends to determine their end use - either consumption or investment. Remittances of under US\$1,000 a year tend to be spent mostly on consumption, primarily food, clothing, and medical care. Remittances of US\$1,000-5,000 
tend to finance durables, often furniture and cars, to invest in home repairs and improvements, and to finance small-scale import transactions. Remittances exceeding US $\$ 5,000$ are mainly used to invest in rural house construction, while those exceeding US $\$ 10,000$ are invested in the remodeling of city apartments and larger-scale imports. Although initially nearly all remittances were used for subsistence, there are indications that at least part of them is being directed toward investment.

Remittances have contributed to financing the trade deficit and kept the current account deficit manageable. Remittances covered up to 80 percent of the growing trade deficit, which reached 19 percent of GDP 2004, driven by real growth and high import demand. This has been the only continuous flow of financing for the trade deficit since early 2000. As inflows of remittances may be under-recorded in the balance of payments, the negative balance of the current account could also be lower than reported.

Remittances and labor migration have had a positive impact on public finances. Imports boosted by remittances are a source of additional revenue collection in the form of VAT and import duties. In 2000-2004 imports increased on average by 15 percent annually. As emigration has eased the unemployment problem and helped contain the associated fiscal expenditures, it can be seen as alleviating the fiscal burden of government. In addition, the consequent remittances can be seen as providing a social safety net, which otherwise would have to be met by the government. Remittances have also contributed to exchange rate stability and even to some exchange rate appreciation that contained and somewhat reduced expenditure in local currency on the external debt serviced by the government. This experience is at slight variance with some other countries, where strong inward flows of remittances created instability of the exchange rate.

Remittances have helped to strengthen the banking system and enhanced competition. With simplified regulations for bank transfers, whereby the recipient does not need to have a current account with the bank to receive remittances, the banks have to compete with each other and other financial intermediaries (i.e., Western Union) for customers. Nevertheless, for many Tajiks receipt of remittances represent their first contact with the banking system. The NBT survey of remittances revealed that while 96 percent of the respondents were happy with bank services, 82 percent were still not prepared to deposit remitted amounts in the banks (with 62 percent citing the need to finance current household and business transactions). While only a small proportion of remittances are deposited, even these amounts have helped the banking system to expand credit access to the private sector. As more recipients gain the confidence needed to deposit remittances, the scope for financial intermediation will grow and the burden of cotton sector debt will decline. More specifically, remittances have helped strengthen the financial base of microfinance institutions, which in turn will be important in channeling remittances to productive use.

Remittances and labor migration have contributed to poverty reduction and human capacity building. Since remittances mainly finance primary consumption, their impact on poverty 
alleviation has been substantial. The poverty rate ${ }^{6}$ in Tajikistan declined from 81 to 60 percent in 2000-2003. Although the precise impact of remittances on this decline is not known, it is likely to be positive. In households receiving remittances, children usually enjoy better education through private tutoring, and all family members tend to have access to better healthcare and other personal services. Also, labor migration has reduced local labor supply and as such has been one of the factors generating growth in wages in the private sector. Remittances have boosted the overall reservation wage, as Tajiks returning from abroad expect higher wages at home.

Remittances may be more efficient as a source of development finance than official development assistance. Remittances are based on private incentives and mainly take place between members of the same household. Intra-family transfers give no direct incentive for corruption. Both senders and recipients are likely to be more concerned about the efficiency of their transfers than may be the case in the public sector. Although a fraudulent banking system can be a major impediment to remittances, in Tajikistan even marginal improvements in banking services, reduction of costs of money wiring, and assurances of unrestricted withdrawals of such transfers have been sufficient to change the attitude to banking from one of hostility to acceptance. Actually, the whole visible inflow of remittances through the banking system started from a simple administrative act - the abolition of a tax on their withdrawal from banks in Tajikistan.

The longer-term impact of remittances will depend largely on their pattern. While in many countries remittances have been a relatively stable source of external financing-more stable than foreign investment or development aid - they can still be volatile and should be viewed as being composed of a permanent and a variable component. The permanent flow of remittances from those Tajiks and ethnic Russians living continuously abroad can be seen as an additional source of stable development financing, whereas remittances by seasonal workers will most likely remain highly volatile, vulnerable to political and economic conjuncture and largely countercyclical, and should not be viewed as a reliable source of sustainable financing.

\section{Policy Challenges of Remittances}

At the same time, the inflow of remittances presents significant challenges for macroeconomic management. Remittances can be considered neither as a solid foundation for longer-term growth, nor as a sustainable development strategy. Consumption, not investment, tends to be the primary goal of remittances. Most remittances are altruistically motivated income transfers by relatives to their families left in Tajikistan. ${ }^{7}$ As such, they are

\footnotetext{
${ }^{6}$ Defined as the percent of total population living on less than US $\$ 2.15$ per day, based on PPPexpenditures.

${ }^{7}$ There are also several other motives for remittances, i.e., motives of self-interest (investment), or implicit family contracts of "loan repayment type" or "co-insurance type". See Solimano (2003) for details.
} 
intended to offset the authorities' economic failures by supporting immediate private consumption, rather than to finance investment needed to underpin longer-term growth. The weak overall investment climate contributes to the fact that-irrespective of the inflows - the investment ratio remains below 15 percent, and more remittances are used on imports rather than on productive domestic investment and job creation, apart from residential construction.

The inflow of remittances impedes monetary management and can rekindle inflationary pressures. In a small economy with a shallow foreign exchange market and insufficient instruments for the conduct of monetary policy, the sheer magnitude of foreign currency inflows and their pronounced seasonal pattern create significant uncertainties for monetary management. In the environment of unstable money demand and a largely impulsive transmission mechanism, the need to sterilize the large inflows of foreign exchange can result in an overshooting of reserve money targets and translate into higher inflation. On the other hand, migration, by reducing the excess labor supply, tends to raise domestic wages and, in the case of Tajikistan, bring them closer to the regional norm. While increased wages make labor less competitive, any improvement in living standards or reduction in poverty would have the same effect. Higher wages may have a more significant inflationary impact only if the outflow of migrants is temporary and the excess labor returns to the home country. However, historically labor movement has been much more stable than financial flows and commodity trade. In addition, accounts held by migrants abroad present a technical problem for monetary management: how to measure money supply in a country where a large number of residents have ATM bank cards linked to accounts in other countries?

The inflow of remittances may lead to an appreciation of the national currency, which can potentially hamper competitiveness. However, developments in the balance of payments, in particular the growing trade deficit, have tended to offset the strong appreciation pressures stemming from the inflow of remittances. Competitiveness has also been largely unaffected, because of the overall low costs in Tajikistan compared to its trading partners, notably labor. However, growing confidence in the local currency will inevitably translate to a higher demand for it for both transaction and saving purposes, making the appreciation pressures self-reinforcing. In fact, during most of 2004, the somoni was under strong pressure to appreciate, reinforced by the falling dollar.

Remittances contribute to the expansion of the trade deficit. A substantial portion of remittances is used to finance imports, as most consumer goods, other than traditional food, and virtually all investment goods, are imported. While exports grew by an average of 16 percent in 2003-2004, the expansion of imports by 22 percent can be attributable largely to remittances. Although the net inflow of remittances has so far helped to cover the largest part of the trade deficit, booming domestic demand for imported consumer goods will eventually stimulate a further increase of remittance-financed imports. This may bring the current account to the brink of sustainability, if remittances are not captured as its integral item.

Remittances create a strong disincentive for domestic savings. Current consumption financed by a steady inflow of remittances creates the illusion of financial stability in households, which manifest a strong preference for receiving philanthropic transfers from abroad rather than saving from domestic sources. Declining domestic savings can potentially deplete the 
resource base for investment and even turn negative, as has already happened in a number of high-remittance countries.

Remittances outside the banking system may be a more fertile ground for money laundering than remittances through the banking system. The development of uncontrolled moneytransmitting arrangements, which are largely outside the National Bank's supervision, and which account for a similar amount of transfers as the banking system itself, may suggest the existence of a parallel payments system in Tajikistan. This system is privately owned, international in nature, and highly efficient. The informal bankers know their clients well, most likely by face. However, this system does not require any proof of the legality of the source of the remitted money nor any indication that all taxes have been paid on the income by the remitter. Such elements are exactly what is needed for money laundering, drug money flows, and ultimately the financing of terrorism. However, limiting such informal transfer mechanisms in the name of fighting illegal activities requires careful handling as it can drive most of such transactions even further underground and lead to more disintermediation.

Remittances reflect the continued exodus of labor from Tajikistan. If labor is merely treated as a commodity of a comparative advantage, the country may end up in a long-term path of continuous migration, marginal foreign investment, and latent growth. The current flood of emigration consists mainly of unskilled, able-bodied young people, which is already depriving the country of its future manpower. The departure of skilled labor (teachers, doctors, engineers) is also important, although less visible statistically; in fact, the average level of education of a Tajik migrant is substantially higher than the average for the population, suggesting a substantial brain drain.

Although remittances help growth, they simultaneously depend on growth. Increases in remittances may point to either weak growth in the home country, which stimulates emigration, or to higher growth in host countries, bringing higher earnings to migrant workers who can then afford to send larger remittances home. Moreover, remittances cannot be viewed a sustainable source of financing, as they may become extremely volatile if the political and economic conjuncture change, both in Tajikistan and the host countries. In this sense, remittances can be a potential source of additional economic vulnerability.

Finally, the inflow of remittances represent a serious moral hazard problem, diminishing pressure for reforms. This type of philanthropically-supported consumption creates an unfortunate illusion of growing and sustainable affluence, which often hinges on broken families, humiliating employment conditions abroad, and harassment associated with carrying cash. The ability of the private sector to address its immediate needs independently from the government can create a disincentive for the authorities to create a better business environment and to deal aggressively with the underlying economic and structural problems that forced the people to leave the country initially.

\section{Conclusions}

There is no obvious blueprint for establishing unambiguously the direction of the macroeconomic impact of remittances. Their ultimate macroeconomic impact will depend on the structural characteristics of a particular economy, the country-specific transmission 
mechanisms, and elasticities, primarily the marginal propensities to import, consume and invest. Remittances are most likely to drive private sector and overall growth, and have minimal negative spillovers in economies whose marginal propensity to invest and to import are high; they are unlikely to have any lasting impact on growth in countries whose marginal propensity to consume is high. If remittances are spent mainly on consumption of non-traded domestic goods, some countercyclical smoothing is the best positive outcome that can be expected, whereas the chances of a real appreciation, either through the nominal exchange rate or inflation, with its possible negative repercussions, are also very high.

Labor migration and flow of remittances have played a significant role in improving growth and reducing poverty in Tajikistan. This has had a significant impact on the balance of payments and has helped to smooth the economic and social impact of transition. However, given the size of the phenomenon, it also implies some risks, as a large proportion of the labor force has left the country. The authorities should continue to give careful consideration to the implications of such remittances on the design and implementation of monetary and exchange rate policies, and in the context of the evolution of the balance of payments. In the financial area, it is particularly important that the authorities seek to avoid any negative impact of remittances (possibly through informal channels) on the development of the banking sector, in particular those that might compromise its integrity. Although the high level of remittances has underpinned economic growth, this source of growth should not detract the authorities from the urgency of reform.

The authorities, together with their development partners, need to come to a judgment as to whether or not remittances are likely to be a permanent phenomenon in Tajikistan. Drawing on the experience of other countries which have managed significant inflows of remittances (Bangladesh, El Salvador, Jordan) could be an important starting point. Also, conducting a comprehensive survey to assess the actual scale of remittances and labor migration would help the authorities to develop a well-defined strategy to maximize the benefits of remittances while minimizing any negative repercussions. Such a survey should seek to understand the motivation for labor migration, migration patterns, the skill distribution of emigrating labor and its remitting potential, as well as other factors that may influence the inflow of remittances in the future. 


\section{Appendix I. Possible Theoretical Treatment of RemitTances}

The Keynesian model. Driven by remittances, an increase in income and therefore demand, has a magnified effect on real GDP growth. The magnification depends on the multiplier and the size of remittances. The multiplier itself depends on marginal propensities to import and to save. In the Keynesian model investment $(I)$ and exports $(X)$ are completely autonomous from the level of output $(Y)$. Therefore, an increase in a country's overall income by way of remittances $(R)$ can be represented either as an autonomous increase in export receipts or as additional investment. Savings $(S)$ and imports $(M)$ consist of an autonomous component independent of $Y$, and an incomeinduced component. In a spending-output space, where $S$ and $M$ are seen as leakages and $I$ and $X$ as injections, an additional inflow $R$ will initially lead to an increase in equilibrium output

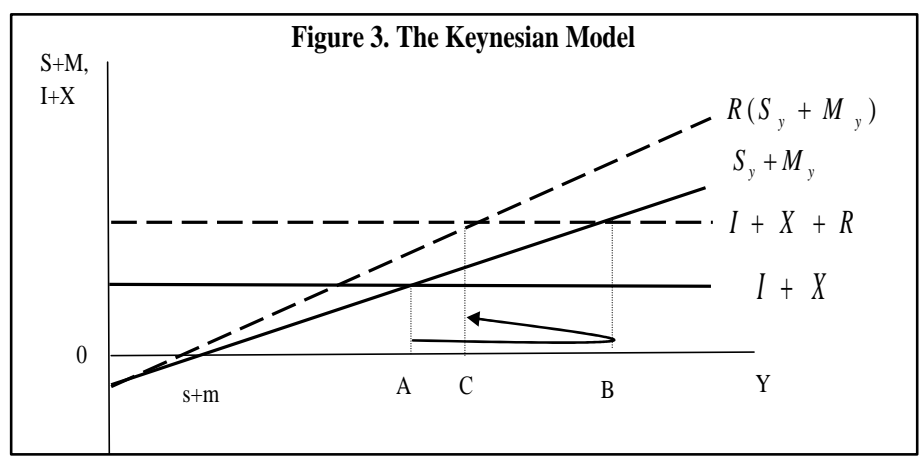
from $A$ to $B$. However, the final equilibrium will crucially depend on the impact of $R$ on the marginal propensities to import $(m)$ and to save (s). Most likely, both will also increase, and the concomitant leakage will push the final equilibrium back from $B$ to $C$, with the output level only marginally higher than the original. If $m+s=1$, the Keynesian multiplier equals unity, and the whole amount of $R$ will be leaked with $Y$ unchanged. The more open the economy, the smaller the multiplier and the less significant the impact of remittances on output.

The Mundell-Fleming model. The impact of a nominal shock on real growth depends on the exchange rate regime and the degree of capital mobility. Assume that capital flows do not react to changes in the interest rate and are overall insignificant, remittances therefore can be viewed as part of the money supply. Monetary policy is an efficient instrument for stimulating real growth under a flexible exchange rate arrangement and inefficient with a fixed exchange rate regime. In the real income $(Y)$ and real interest rate (i) space, the real (IS), monetary $(L M)$ and external $(B P)$ sectors are in simultaneous equilibrium, when output is at $Y_{1}$ and the interest rate is at $\left(i_{1}\right)$. The $B P$ curve is perfectly inelastic as

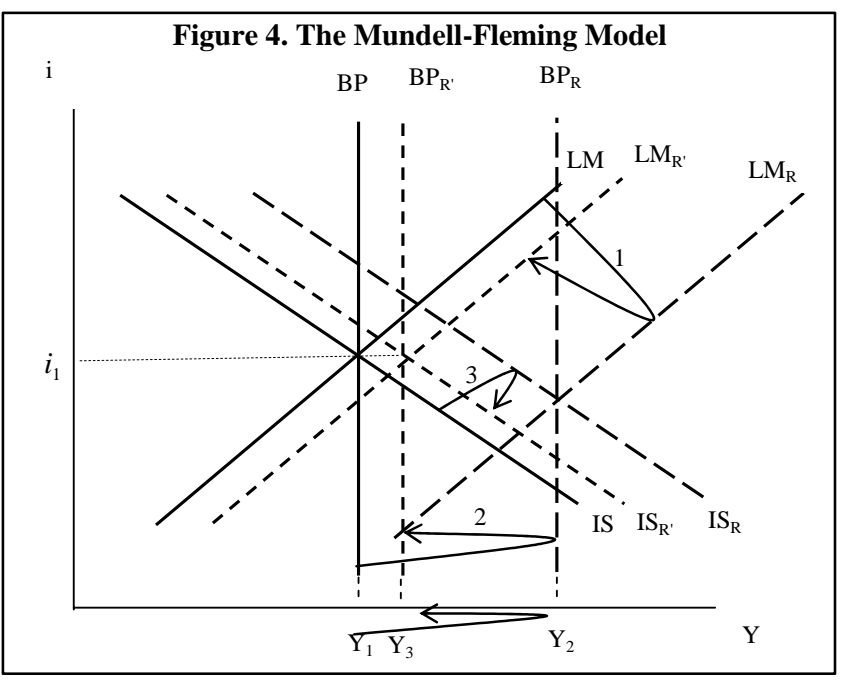
capital flows do not respond to changes in the interest rate. Driven by the inflow of remittances $(R)$, the expansion of money supply to $L M_{R}$ in principle should immediately 
produce a substantial growth in output to $Y_{2}$, making more domestic credit available.

However, the inflow of foreign exchange and the corresponding rise in demand for local currency will cause pressure on the exchange rate toward its appreciation. The resulting decline in export demand and the incipient balance of payments deficit will hamper all, or at least a significant part, of the initial impact of the monetary expansion on growth and can reduce output from $Y_{2}$ to $Y_{3}$, where $Y_{3}>Y_{1}$ or-at the extreme and depending on elasticities - it can even be that $Y_{3} \leq Y_{1}$. Money demand adjusts to the lower output level. But as the interest rate declines, real sector activity may pick up driven by higher investment financed by remittances. Therefore, even with contracting export demand, the ultimate outcome of the adjustment to the inflow of remittances depends on the behavior of the real sector. With increased investment helping growth, and appreciation hampering it, the outcome is ambiguous. In the best-case scenario, the whole economy moves to a new equilibrium with just a slightly higher output level at $Y_{3}$, and an interest rate equal, higher, or lower when compared to its pre-remittances level.

The Rybczynski effect. In an extension of the Heckscher-Ohlin model, labor emigration can be seen as a decreased availability of the factor of production in the home country, with the impact on growth depending on the behavior of other factors and the degree of substitution among them. If the economy produces two key goods-one labor intensive and the other capital intensive, using two factors, labor $(L)$ and capital $(K)$, an exodus of labor will shift the PPF inwards along the axis of the labor-intensive commodity, from $L_{1}$ to $L_{2}$. The impact of a lower labor supply on capital is ambiguous: on the one hand, less capital may be needed for the labor-intensive good, on the other hand, new capital inflow can substitute for the declining factor. Assuming that the decline in labor is accompanied by an increase in capital, the PPF shifts in an asymmetrical manner, from $P P F_{1}$ to $P P F_{2}$. As in the case of a small country, the relative price between the two goods will not change

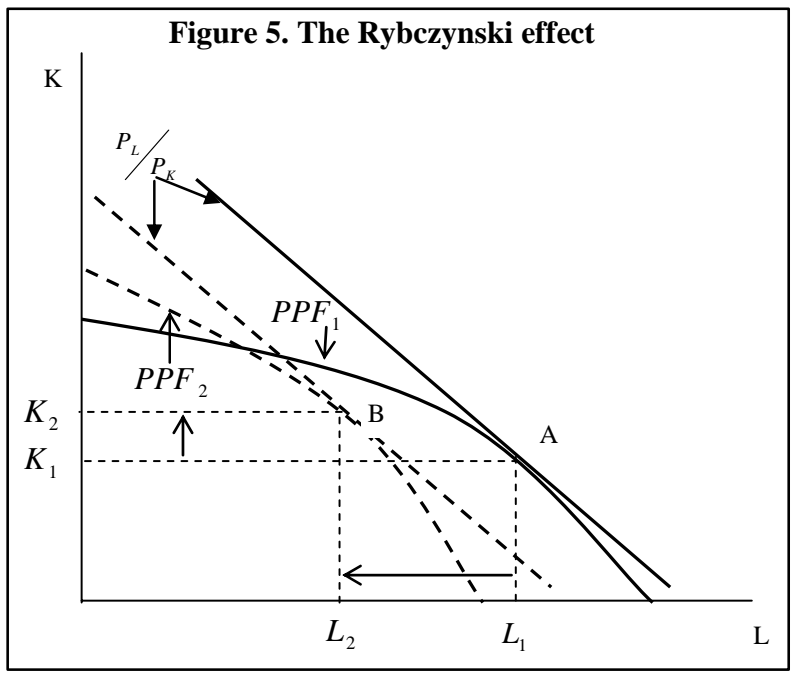
$\left(\frac{P_{L}}{P_{K}}\right)$, and the production point will move from the point of tangency $A$ to $B$. As the final shape of $P P F_{2}$ is unknown, the position of $B$ is also uncertain. As is shown, however, the output in the labor-intensive good declines and the output of the capital-intensive good increases.

This is the well-known Rybczynski theorem in reverse: contraction in one factor will lead to an absolute contraction of the output and exports of the product that uses that factor relatively more intensively and an absolute expansion in the output and exports of the good that uses another factor intensively. As labor is assumed to be an abundant factor, its contraction should have an ultra-antitrade production effect. However, the total impact on trade requires 
the estimation of both production and consumption effects. As a general rule, if the consumption effect is pro-trade, the country's participation in trade will decline with the decline in the abundant factor. The welfare implication of the decline in the abundant factor should be positive, as per capita income of those left in the home country would increase. In the case of Tajikistan, the described move from point A, which is at the PPF, i.e. full employment, towards point B inside the frontier, can also be viewed as the reverse of reality as countries that are a source of migrants are usually characterized by high unemployment.

A national accounts approach. The direct impact of remittances is an increase in aggregate demand defined in this case as gross national disposable income $Y=(C+I)_{p}+(C+I)_{g}+(X-M+N Y+N C T)$, where the latter two components--net factor income $(N Y)$ and net current transfers $(N C T)$--capture remittances and the last bracket is current account balance $(C A B)$. Unlike aid, which works into the economy through the official accounts, remittances, as private flows, initially only affect private consumption and investment, i.e. $(C+I)_{p}$. As long as the economy is operating below potential, an increase in consumption should be supported either by higher domestic output or higher imports. Therefore, one immediate consequence of remittances is a higher private component of the aggregate demand.

Once remitted to the home country, remittances can be saved, consumed, or invested.

- $\quad$ Assume first that all remittances are saved. As $S=Y-C=I+C A B$ and if remittances are saved by the private sector at a given level of income, private sector consumption should decline. The impact on investment is ambiguous, however, as it depends on the response of the current account. If remittances are saved in dollars outside the banking system, their inflow has no monetary implications. If they are deposited, the foreign currency component of broad money supply will increase. If remittances are converted into local currency but saved outside the banking system, they will create upward pressure on the exchange rate, but without impact on recorded money supply. If they are converted into local currency and deposited in banks, they contribute to both exchange rate appreciation and an increase in money supply.

- $\quad$ Assume now that all remittances are consumed. As $C=Y-I-C A B$ at a given level of income, private consumption can increase only if investment declines with an unchanged current account or the current account deteriorates with unchanged investment. Any increase in investment in parallel with growing consumption leads to a significant current account deterioration.

- $\quad$ Assume finally that all remittances are invested. Along the same line of reasoning, as $I=Y-C-C A B$, an increase in private investment at the given level of overall income can be the result of either a decline in consumption with unchanged current account or a deterioration in the current account with unchanged consumption. Any simultaneous increase in investment and consumption requires significant current account deterioration. 
The impact on output and consumption from the shift in relative prices is less obvious. If the country initially produces and consumes a combination of traded (TG) and non-traded goods (NTG) at $C_{1}$ and with the relative price in $P_{T} / P_{N}$, the inflow of remittances $R$ increases demand $C_{F}$. Without shifting relative prices, this will imply a trade deficit of $T G_{2}-T G_{1}$, equal to remittances times marginal propensity to spend on traded goods, and an excess demand for non-tradables of $N T G_{2}-T G_{2}$. If remittances are spent mainly on tradables, their relative price will increase to $P_{T} / P_{N} *$, which would help raise output of tradables to $T G_{3}$ and to produce a new combination $Y$ of tradable and non-tradable goods. While the impact on output is clearly favorable, the impact on consumption is again ambiguous. The new consumption point can be placed somewhere like $C_{3}$ where the steeper expenditures financed by remittances is tangential to a new indifference curve, which in practice can be located either to the left or to the right of $C_{2}$, depending on the unknown concavity of the transformation curve and suggesting a decline or increase of consumption, respectively. 


\section{REFERENCES}

Adams, Richard H., 2003, International Migration, Remittances, and the Brain Drain: A Study of 24 Labor-Exporting Countries (Washington: World Bank).

Alfieri, Alessandra, and Ivo Havinga, 2000, "Definition of Universe for the Framework on the Movement of Natural Persons," Meeting of the Technical Subgroup on Movement of Natural Persons-Mode 4, Paris, January 31-February 1, 2000.

Alfieri, A., I. Havinga, and J. Schwarzler, 2004, Statistical Framework for the Measurement of Mode 4, A proposal, draft.

Alfieri, Alessandra , Ivo Havinga, and Vetle Hvidsten, 2005, "Definition of Remittances and Relevant BMP5 Flows," UN Department of Economic and Social Affairs Statistics, Meeting of the Technical Subgroup on Movement of Natural Persons-Mode 4, Paris, January 31-February 1, 2005.

Bilsborrow, R.E., G. Hugo, A.S. Oberai, and H. Zlotnik, 1997, International Migration Statistics: Guidelines for Improvement of Data Collection Systems. Geneva: ILO.

Bouhga-Hagbe, Jacques, 2004, “A Theory of Workers' Remittances with an Application to Morocco,” IMF Working Paper No. 04/194 (Washington: International Monetary Fund).

Brown, S., 2004, "Statistics on Remittances,” BOPCOM-04/39 (European Commission, 2004).

Chami, Ralph, Connel Fullenkamp, and Samir Jahjah, 2003, “Are Immigrant Remittance Flows a Source of Capital for Development?," IMF Working Paper No. 03/189 (Washington: International Monetary Fund).

ECFIN, 2004, EU Survey on Workers' Remittances from the EU to Third Countries. Brussels: Directorate General Economic and Financial Affairs (ECFIN), European Commission.

Hamilton, Kimberly, 2003, Migration and Development: Blind Faith and Hard-to-Find Facts (Washington: Migration Policy Institute).

Harrison, A., 2004, "Working Abroad-The Benefits Flowing from Nationals Working in Other Countries, Round Table on Sustainable Development," Vol.1, No.2, (OECD, Migrant Remittances, 2004).

Hussain, Mushtaq, 2005, "Measuring Migrant Remittances: From the Perspective of the European Commission,” European Commission Eurostat, Unit C4.

International Monetary Fund, 2005, World Economic Outlook. Globalization and External Imbalances, April 2005.

International Organization for Migration (IOM), 2003, Labour Migration from Tajikistan. 
Ministry of Economy and Trade of Tajikistan.

Miambo, S.M., and Ratha, D., 2005, Remittances: Development Impact and Future Prospects. (Washington: World Bank).

Olimova, Saodat, and Igor Bosc, 2003, Labor Migration From Tajikistan, International Organization for Migration.

Rapoport, Hillel, and Frédéric Docquier, 2005, The Economics of Migrants’ Remittances.

Ratha, D., 2004, Understanding the Importance of Remittances, (Washington: World Bank).

Reinke, J., N. Patterson, and J. Motala, 2004, Migration and Remittances: A Response to the Mode 4 Proposal from a Balance of Payments Perspectives, IMF Statistics Department.

Reinke, Jens, and Neil Patterson, 2005, Remittances in the Balance of Payments Framework, (unpublished; Washington: International Monetary Fund).

Solimano, A. 2003. Remittances by Emigrants: Issues and Evidence. WIDER Discussion Paper No. 2003/89.

Tajikistan: Remittances - a tool for development, May 18, 2005. Reuters on-line report (IRIN).

World Bank, 2003, Global Development Prospects 2003: Striving Stability for Development Finance”, See Chapter 7-Workers' Remittances: An Important and Stable Source of External Development Finance, April 2003.

World Bank, 2005a, Global Development Finance. Mobilizing Finance and Managing Vulnerability. Analysis and Statistical Appendix , 2004, Poverty Assessment Update, June 2004.

World Bank, 2005b, Tajikistan Trade Study (unpublished). 